\title{
Growth of Candida guilliermondii FTI 20037 on Mixed Substrate
}

\author{
Patrick V. Gurgel ${ }^{1}$, Délia C. Vieira ${ }^{2}$, Sandra A. Furlan ${ }^{2}$, Ismael M. de Mancilha ${ }^{1,2}$ \\ 1 - Departamento de Tecnologia de Alimentos, UFV, 36570-000, Viçosa, MG, BRAZIL; 2 - Departamento de \\ Biotecnologia, FAENQUIL, 12600-000, Lorena, SP, BRAZIL; *Current address - UNIVILLE - Campus \\ Universitário - Bom Retiro - 89.223-900 - Joinville, SC, BRAZIL
}

\begin{abstract}
Candida guilliermondii FTI 20037 was grown on a mixed substrate comprising glucose and xylose. Inocula were grown using xylose or glucose as carbon source. Results showed that xylose utilization was delayed until glucose was utilized. Inoculum prepared on glucose showed a lag phase in xylose consumption. Cell mass production was higher when glucose was utilized during fermentation.
\end{abstract}

Key words: Candida guilliermondii, glucose, xylose, mixed substrate

\section{INTRODUCTION}

Agricultural residues can be utilized by microorganisms in order to produce chemical feedstocks by fermentation. The hemicellulosic portion of these residues needs hydrolysis to get a liquor consisting mainly of xylose and glucose. Thus, it is important to know the behaviour of microorganisms in mixtures of glucose and xylose.

Candida guilliermondii FTI 20037 was found to be a good xylitol producer from xylose (Barbosa et al., 1988), and has shown good performance when grown in sugarcane bagasse hydrolyzate (Gurgel et al., 1992; Roberto et al., 1991).

Panchal et al. (1988) evaluated the fermentation performance of the yeast species Pichia stipitis, $C$. steatolytica and $C$. shehatae in media containing glucose and xylose at different concentrations. The results revealed that xylose consumption by $P$. stipitis and $C$. steatolytica was repressed when glucose was available. This was not observed for $C$. shehatae, but xylose consumption increased when glucose was depleted. The authors also showed that the minimum glucose concentration to inhibit xylose utilization was $2 \%$ for $P$. stipitis and $3 \%$ for C. steatolytica, while for C. shehatae, a $40 \%$ decrease in the xylose consumption rate was observed when $5 \%$ glucose was present in the medium. Kastner \& Roberts (1990) studied the behaviour of $C$. shehatae. They found that xylose utilization was completely repressed when glucose was present in the medium, regardless of the glucose/xylose ratio. Sreenath et al. (1986) observeed that the addition of small amounts of glucose in a fed-batch fermentation, using $C$. shehatae at low aeration condition, stimulated xylose consumption.

Using C. guilliermondii, Silva et al. (1990) reported that the fermentation of a medium without any glucose resulted improvement in xylose consumption. The authors suggested that the improvement observed was due to the partial inhibition of the enzyme xylose reductase by glucose. This effect was also observed by Lee $e t$ al. (1996), studying the ability of various sugars to induce xylose reductase and xylitol dehydrogenase. They suggested that xylose reductase was repressed when glucose was present in the medium. On the other hand, in fermentation runs with the same yeast strain, an improvement in the fermentation parameters was observed, when glucose was present at low concentration (Felipe et al., 1993). These

\footnotetext{
* Author for correspondence
} 
differences could be attributed to the different xylose/glucose ratio.

\section{MATERIAL AND METHODS}

Candida guilliermondii FTI 20037 from slants of malt extract agar was grown at $30^{\circ} \mathrm{C}$ and 200 $\mathrm{min}^{-1}$ in Erlenmeyer flasks containing $100 \mathrm{~mL}$ of a medium with $(\mathrm{g} / \mathrm{L}):\left(\mathrm{NH}_{4}\right)_{2} \mathrm{SO}_{4} 3.0$; $\mathrm{CaCl}_{2} .2 \mathrm{H}_{2} \mathrm{O} \mathrm{0.1}$; rice bran 20.0; and xylose or glucose 30.0 The inocula (Table I), grown on xylose $(\mathrm{X})$ or glucose $(\mathrm{G})$, were utilized to inoculate media with the same basic composition containing different sugar amounts. Fermentations were carried out in $500 \mathrm{~mL}$ Erlenmeyer flasks containing $200 \mathrm{~mL}$ of media at $30^{\circ} \mathrm{C}$ and agitation of $200 \mathrm{~min}^{-1}$.

Table I: Sugar concentration in the different treatments

\begin{tabular}{|c|c|c|c|c|}
\hline \multirow{2}{*}{ Treat. } & \multicolumn{2}{|c|}{ Inoculum } & \multicolumn{2}{c|}{ Growth } \\
\cline { 2 - 5 } & $\begin{array}{c}\text { Xylose } \\
(\mathrm{g} / \mathrm{L})\end{array}$ & $\begin{array}{c}\text { Glucose } \\
(\mathrm{g} / \mathrm{L})\end{array}$ & $\begin{array}{c}\text { Xylose } \\
(\mathrm{g} / \mathrm{L})\end{array}$ & $\begin{array}{c}\text { Glucose } \\
(\mathrm{g} / \mathrm{L})\end{array}$ \\
\hline $\mathrm{X} 1$ & + & - & 30 & - \\
\hline X2 & + & - & 15 & 15 \\
\hline X3 & + & - & 18 & $12^{*}$ \\
\hline G1 & - & + & - & 30 \\
\hline G2 & - & + & 15 & 15 \\
\hline G3 & - & + & 18 & $12^{*}$ \\
\hline G4 & - & + & $12 *$ & 18 \\
\hline G5 & - & + & 30 & - \\
\hline
\end{tabular}

Cell growth was measured turbidimetrically at $540 \mathrm{~nm}$. Glucose and xylose concentrations were measured by HPLC according to Roberto et al. (1991).

\section{RESULTS AND DISCUSSION}

Figure 1 shows the behaviour of $C$. guilliermondii at three different conditions. Treatment G1 consisted of using glucose for inoculum preparation. It was observed that there was no lag phase in substrate consumption and the sugar was consumed in approximatelly $10 \mathrm{~h}$. Moreover, growth stopped when sugar was depleted, reaching a cell concentration of 7,3 g/L. Treatment X1, growing cells on xylose (inoculum preparation on xylose), showed no lag phase on substrate consumption. It was also observed that growth rate decreased after $10 \mathrm{~h}$ of growth, reaching a cell concentration of $3,7 \mathrm{~g} / \mathrm{L}$. However, the cells continued to grow up to a concentration of $4,4 \mathrm{~g} / \mathrm{L}$ at $24 \mathrm{~h}$ cultivation, without a complete consumption of the xylose available. In treatment G5, in which glucose was used for inoculum preparation and xylose for growing cells, it was observed that there was a delay in substrate consumption, when compared to treatment G1. Xylose consumption started after $6 \mathrm{~h}$, and growth rate during exponential phase was lower than in treatments $\mathrm{G} 1$ and $\mathrm{X} 1$, but reaching the same final value of cell mass $(4,3 \mathrm{~g} / \mathrm{L})$ as for treatment X1. Residual xylose, after $24 \mathrm{~h}$ of fermentation was very high, when compared to treatment X1. These observations suggested that the utilization of xylose involved non-constitutive enzymes, which was also stated by Webb \& Lee (1990). The results also showed that cell mass production was more effective using glucose as carbon source.

The behaviour of $C$. guilliermondii growing on xylose and glucose combinedly, using xylose or glucose in the inocula, is shown in Figure 2. The results showed that in the treatment using glucose in the inoculum preparation (treatment $\mathrm{G} 2), \quad C$. guilliermondii consumed glucose preferentially, as mentioned by Lee et al. (1996). The same behaviour was observed when the sugar utilized in the inoculum preparation was xylose (treatment X2), which was also observed by Heredia \& Ratledge (1988) for $C$. utilis and C. tropicalis, while C. curvata showed a simultaneous consumption pattern.

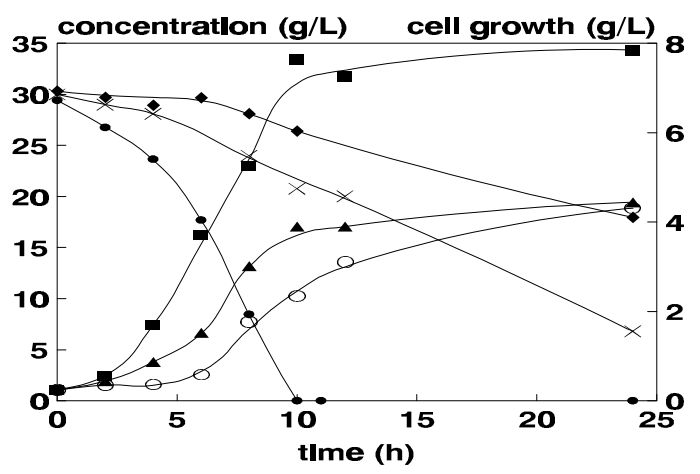

Figure 1: Xylose and glucose consumption and cell growth of $C$. guilliermondii under treatments G1, X1 and G5. Symbols: • G1-glucose, $\times$ X1-xylose, G5-xylose, $\mathbf{\square}$ G1-cell growth, $\boldsymbol{\Delta} \mathrm{X} 1$-cell growth, $\mathrm{O}$ G5-cell growth. 
Kastner \& Roberts (1990) reported a simultaneous utilization pattern for glucose and xylose when inoculum of $C$. shehatae was prepared on xylose, and a sequential pattern (glucose first) when the cells were grown on glucose. It could be observed (Figure 2) that glucose consumption in treatment $\mathrm{X} 2$ was slower than in treatment $\mathrm{G} 2$, but xylose comsumption patterns were similar. A similar pattern for cell mass production was observed in both treatments, but X2 was delayed by 1 to $2 \mathrm{~h}$ when compared with G2. Growth was drastically diminished when glucose was consumed.

The final value of cell mass concentration in treatments X2 and G2 were lower than in treatment $\mathrm{G} 1$, probably due to the glucose concentrations in G1 $(30 \mathrm{~g} / \mathrm{L})$. These values were higher than the ones obtained in treatments $\mathrm{X} 1$ and G5, utilizing xylose as carbon source. This observation seemed to confirm that glucose was a more effective carbon source for growth than xylose for $C$. guilliermondii.

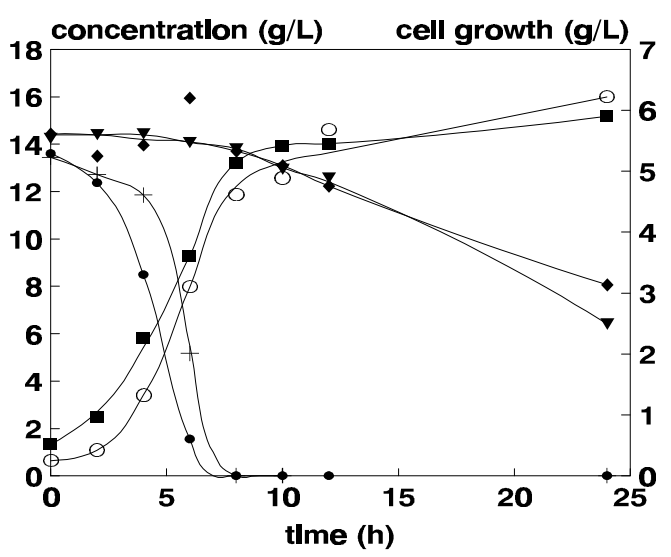

Figure 2: Xylose and glucose consumption and cell growth of $C$. guilliermondii under treatments $\mathrm{G} 2$ and X2. Symbols: - G2-glucose, $\bullet$ G2-xylose, + X2glucose, $\nabla$ X2-xylose, $\square$ G2-cell growth, $\mathrm{O}$ X2-cell growth.

Figure 3 shows the effect of a pulse of sugar (xylose or glucose) on the fermentation. The results related to treatment G3 did not show any xylose consumption during the first $6 \mathrm{~h}$, as in treatment G5 (Figure 1), when a glucose pulse was applied. Xylose started to be consumed only when glucose was consumed after $12 \mathrm{~h}$ of fermentation. The results of treatment G4 showed that there was a lag phase when the inoculum was prepared using glucose and the carbon source for growing cells was xylose, as in treatment G5. Cell mass production in treatment G4 (Figure 4) showed a similar pattern, compared to G1 (Figure 1), but with a final concentration slightly lower. This could be due to the lower amount of glucose available (18 $\mathrm{g} / \mathrm{L}$ in $\mathrm{G} 4$ and $30 \mathrm{~g} / \mathrm{L}$ in G1). The results of treatment G3 showed good growth performance when glucose was present, and showed a great decrease when glucose was completely consumed (Figure 4).

The results related to treatment $\mathrm{X} 3$ showed the inhibition of xylose consumption by glucose. It was seen that xylose consumption stopped during glucose pulse, and it started again after glucose was depleted. The same effect could be observed in the growth curve (Figure 4), which showed a step at the beggining of glucose consumption. Kilian \& Van Uden (1988), working with $P$. stipitis suggested that glucose competed with xylose for transport in a lowaffinity system and inhibited xylose transport by a high-affinity system non-competitively.

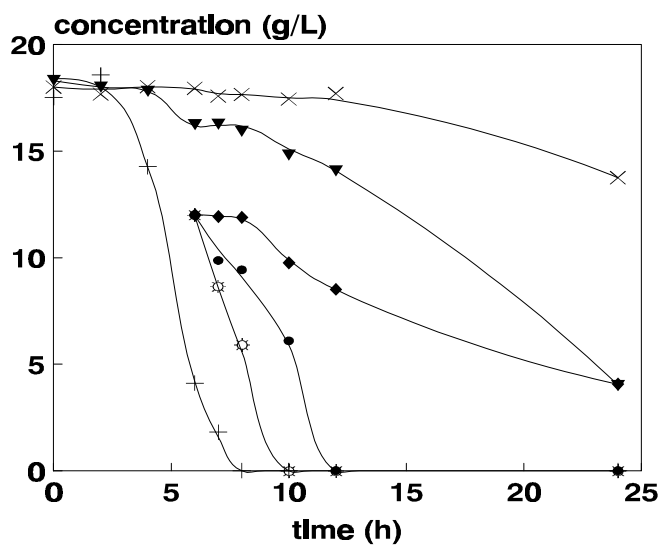

Figure 3: Xylose and glucose consumption by $C$. guilliermondii in treatments G3, G4 and X3. Symbols: $\bullet$ G3-glucose, $\times$ G3-xylose, + G4-glucose, $\checkmark$ G4-xylose, 0 X3-glucose, $\nabla$ X3 xylose. 


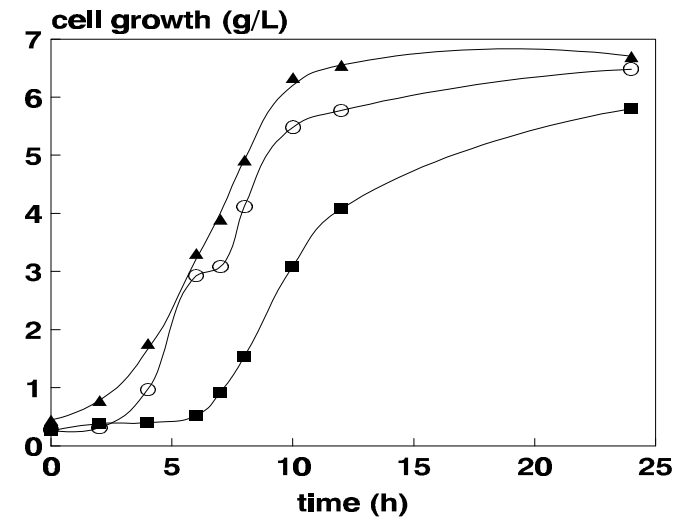

Figure 4: Cell growth behaviour of $C$. guilliermondii in treatments G3, G4 and X3. Symbols: aG3-cell growth, $\Delta$ G4-cell growth, $\bigcirc \mathrm{X} 3$-cell growth.

\section{CONCLUSIONS}

From the above results, it could be concluded that glucose and xylose consumption by $C$. guilliermondii FTI 20037 followed a sequential pattern, which suggested that the utilization of xylose might be regulated by induction and catabolite repression. It could also be concluded that inoculum prepared on xylose were able to metabolize this sugar faster than inoculum prepared on glucose, which took a longer time to adapt to a new carbon source. Glucose seemed to be a better carbon source for cell mass production by $C$. guilliermondii FTI 20037.

\section{ACKNOWLEDGEMENTS}

P.V. Gurgel, D. C. Vieira and S.A. Furlan were supported by fellowship from Conselho Nacional de Desenvolvimento Científico e Tecnológico (CNPq).

\section{REFERENCES}

Barbosa, M.F.S.; Medeiros, M.B.; de Mancilha, I.M.; Schneider, H. and Lee, H. (1988), Screening of yeasts for production of xylitol from D-xylose and some factors which affect xylitol yield in Candida guilliermondii. J. Ind. Microbiol., 3, 241-251.

Felipe, M.G.A.; de Mancilha, I.M.; Vitolo, M.; Roberto, I.C.; Silva, S.S. and Rosa, S.A.M. (1993), Preparação de xilitol por fermentação de hidrolisado hemicelulósico de bagaço de cana de açúcar. Arq. Biol. Tecnol., 36, 101-114.
Gurgel, P.V.; Queiróz, M.A. and de Mancilha, I.M. (1992), Effect of the aeration rate on bioconversion of D-xylose to xylitol. Paper presented at the $9^{\text {th }}$ Int. Biotechnol. Sym. Exp., 16-21 Aug., Crystal City, USA.

Heredia, L. and Ratledge, C. (1988), Simultaneous utilization of glucose and xylose by Candida curvata D in continuous culture. Biotechnol. Lett., 10, 25-30.

Kastner, J.R. and Roberts, R.S. (1990), Simultaneous fermentation of D-xylose and glucose by Candida shehatae. Biotechnol. Lett., 12, 57-60.

Kilian, S.G. and Van Uden, N. (1988), Transport of xylose and glucose in the xylose-fermenting yeast Pichia stipitis. Appl. Microbiol. Biotechnol., 27, 545548.

Lee, H.; Sopher, C.R. and Yau, K.Y.F. (1996), Induction of xylose reductase and xylitol dehydrogenase activities on mixed sugars in Candida guilliermondii. J. Chem. Technol. Biotechnol., 66, 375-379.

Panchal, C.J.; Bast, L.; Russel, I. and Stewart, G.G. (1988), Repression of xylose utilization by glucose in xylose-fermenting yeasts. Can. J. Microbiol., 34, 1316-1320.

Roberto, I.C.; Felipe, M.G.A.; Lacis, L.C.; Silva, S.S. and de Mancilha, I.M. (1991), Utilization of sugar cane bagasse hemicellulosic hydrolysate by Candida guilliermondii for xylitol production. Biores. Technol., 36, 271-275.

Silva, S.S.; Roberto, I.C.; Felipe, M.G.A. and de Mancilha, I.M. (1990), Efeito da agitação e influência da glicose na fermentação de xilose a xilitol. Paper presented at the "Congresso Latino Americano de Biotecnologia", 7-11 Aug., La Habana, Cuba.

Sreenath, H.K.; Chapman, T.W. and Jeffries, T.W. (1986), Ethanol production from D-xylose in batch fermentations with Candida shehatae: process variables. Appl. Microbiol. Biotechnol., 24, 294-299.

Webb, S.R. and Lee, H. (1990), Regulation of D-xylose utilization by hexoses in pentose fermenting yeasts. Biotech. Adv., 8, 685-697.
Recceived: August 19, 1998; Revised: August 24, 1998; Accepted: November 09, 1998. 